\title{
VAP Rates Unchanged
}

In a research letter to JAMA Metersky and colleagues (1) report that ventilatorassociated pneumonia (VAP) rates have remained near $10 \%$ since 2005 . The authors reviewed Medicare Patient Safety Monitoring System (MPSMS) data on a representative sample of more than 86,000 critically ill patients treated at 1330 US hospitals between 2005 and 2013. To meet a diagnosis of VAP patients were required to have at least 2 days' ventilation in intensive care units; a chest radiograph with a new finding suggesting pneumonia; a physician diagnosis of pneumonia; and an order for antibiotics. VAP incidence was 10.8\% $(95 \%$ confidence interval, 7.4\% - 14.4\%) during 2005 to 2006 and $9.7 \%$ (95\% confidence interval, $5.1 \%$ - 14.9\%) during 2012 to 2013.

In contrast, data from the CDC's National Healthcare Safety Network (NHSN) have shown declines in VAP rates of $71 \%$ and $62 \%$ in medical and surgical intensive care units, respectively, between 2006 and 2012 (2,3). "The most likely explanation for the discrepancy is thought to be bias in reporting to CDC by the hospitals," Dr. Metersky told Medscape Medical News (4). Dr. Charles S. Dela Cruz at Yale agrees. "Strict and varying VAP measure definitions and the hospital reporting mechanisms possibly contributed to the differences in rates," he said.

VAP has no standard definition and its diagnosis has considerable clinical variability. Other than removing the endotracheal tube as quickly as possible, VAP prevention guidelines are non- or weakly evidence-based (5). Furthermore, financial incentives from CMS for low VAP rates may have contributed to the bias in reporting (6).

Richard A. Robbins, MD Editor, SWJPCC

\section{References}

1. Metersky ML, Wang Y, Klompas M, Eckenrode S, Bakullari A, Eldridge N. Trend in ventilator-associated pneumonia rates between 2005 and 2013. JAMA. 2016 Nov 11. [Epub ahead of print] [CrossRef] [PubMed]

2. Edwards JR, Peterson KD, Andrus ML, et al; NHSN Facilities. National Healthcare Safety Network (NHSN) Report, data summary for 2006, issued June 2007. Am J Infect Control. 2007;35(5):290-301. [CrossRef] [PubMed]

3. Dudeck MA, Weiner LM, Allen-Bridson K, et al. National Healthcare Safety Network (NHSN) report, data summary for 2012, device-associated module. Am J Infect Control. 2013;41(12):1148-66. [CrossRef] [PubMed]

4. Swift D. No drop in VAP rates, study contends. Medscape Medical News. November 21, 2016. Available at: http://www.medscape.com/viewarticle/872157?nlid=110853 3464\&src=WNL 
mdplsfeat 161129 mscpedit ccmd\&uac=9273DT\&spon=32\&impID=1243721 \&faf $=1$ (accessed 12/2/16).

5. Padrnos L, Bui T, Pattee JJ, Whitmore EJ, lqbal M, Lee S, Singarajah CU, Robbins RA. Analysis of overall level of evidence behind the Institute of Healthcare Improvement ventilator-associated pneumonia guidelines. Southwest J Pulm Crit Care 2011;3:40-8.

6. Cassidy A. Medicare's hospital-acquired condition reduction program. Health Affairs. August 6, 2015. Available at:

http://www.healthaffairs.org/healthpolicybriefs/brief.php?brief id=142 (accessed 12/2/16). 